\title{
PERANAN KELUARGA DALAM MEMBENTUK PENDIDIKAN NILAI
}

\author{
Alfurqan \\ Universitas Negeri Padang, Indonesia \\ E-mail: alfurqan@fis.unp.ac.id
}

\begin{abstract}
Abstrak
Keluarga merupakan institusi yang sangat penting peranannya dalam mengimplementasikan pendidikan nilai kepada anak-anak, karena dalam keluargalah anak pertama kali memperoleh pendidikan. Pendidikan nilai bagi anak-anak sebaiknya ditanamkan mulai dari semenjak kecil dan akan lebih baik lagi saat anak berada dalam rahim ibunya. Untuk mengisi nilai-nilai sosial dapat diberikan sesuai dengan situasi dan mengacu pada tujuan yang diinginkan agar dilaksanakan oleh anak. Artinya metode yang diberikan dapat bersifat fleksibel.
\end{abstract}

Kata kunci : peranan keluarga, pendidikan, nilai

\section{A. Pendahuluan}

Keluarga merupakan unit satuan masyarakat yang terkecil sekaligus merupakan suatu kelompok kecil dalam masyarakat. Kelompok inilah yang melahirkan individu dengan berbagai macam bentuk kepribadian dalam masyarakat. Singgih Gumara (1984) menyatakan bahwa keluarga mempunyai fungsi tidak hanya sebatas selaku penerus ketahanan keluarga saja. Banyak hal-hal mengenai kepribadian dapat diurut melalui keluarga; yang saat sekarang sering dilupakan orang . Perkembangan intelektual akan kesadaran lingkungan sosial dan nilai-nilai yang harus dijunjung tinggi seringkali di lepas dari keluarga. Hal semacam inilah yang sering menimbulkan masalah-masalah sosial karena anak akan kehilangan pijakan. Maka adalah bijaksana kalau peranan keluarga tersebut ditinjau dan dikembalikan sesuai dengan proporsi yang sebenarnya.

Dilihat dari keberadaannya, keluarga merupakan institusi yang sangat penting peranannya dalam mengimplementasikan pendidikan nilai kepada anakanak, karena dalam keluargalah anak pertama kali memperoleh pendidikan. Semenjak anak ada dalam rahim ibunya, ibu selalu memeliharanya dengan penuh 
kasih sayang dan harapan agar anak yang dilahirkannya dapat berkembang menjadi manusia yang baik kelak. Pendidikan yang diberikan keluarga disebut pendidikan informal yang tidak terikat oleh waktu dan tempat.

Proeses pendidikan nilai dalam keluarga berjalan sepanjang masa melalui proses interaksi dan sosialisasi dalam kehidupan sehari-hari. Esensi pendidikannya tersirat dalam integritas keluarga baik dalam komunikasi antar sesama anggota keluarga, dalam tingkah laku keseharian orang tua dan anggota lainnya yang merupakan sebuah proses pendidikan bagi anak-anak.

Memang dalam satu keluarga tidak ada kurikulum khusus tentang pendidikan nilai bagi anak-anak. Namun orang tua harus memberikan bimbingan buat anak-anaknya dengan menggunakan metoda yang cocok untuk memberikan pembinaan nilai. Misalnya dalam pendidikan aqidah, akhlak, ibadah dan pendidikan sosial lainnya agar anak dapat menyongsong masa depannya sebagai manusia yang berkepribadiaan luhur

\section{B. Peran Keluarga bagi Anak-anak}

Keluarga adalah unit terkecil dalam masyarakat yang terdiri dari ayah, ibu, anak-anak, nenek atau kakek yang menjadi lingkungan primer tempat anak-anak dibesarkan. Suasana apa yang dilihat dan didengar, dirasakan dalam keluarga akan mempengaruhi pertumbuhan dan perkembangan jiwa dan perilaku anak.

Dalam sebuah keluargalah untuk pertama kali terbentuk hubungan keakraban, secara langsung disitu pula berkembang satu individu baru yang berkenalan dengan tahap-tahap awal proses sosialisasi. Dari interaksi keluarga, anak-anak mendapat didikan dan keterampilan dalam berbagai hal seperti pengembanagn minat, mengenal nilai-nilai, mengendalikan emosi dan sikap toleransi, hingga ia memperoleh ketenangan dan ketenteraman hidupnya.

Pembentukan keluarga yang dimulai secara Islami diawali dengan terciptanya hubungan suci dan sakral menyatukan laki-laki dan perempuan melalui pernikahan yang halal, dengan memenuhi rukun syarat dan syahnya suatu perkawinan. Maka dari itu kedua suami dan istri merupakan unsur utama dari suatu keluarga. Jadi keluarga dapat dikatakan merupakan penyatuan suami dan 
istri untuk bersama dimana yang satu merasa tenteram dengan yang lainnya dan menjalin hidup sesuai dengan ajaran agama (tunduk dengan aturan masyarakat). Bila mereka memperoleh seorang anak atau lebih, anak-anaknya merupakan unsur ketiga dari keluarga tersebut.

Pada keluarga baru itulah individu yang terlahir tadi memulai interaksi sosialnya. Dari proses interaksi itu anak (individu) memperoleh unsur-unsur dasar pembentukan kepribadiannya. Dalam keluarganya itu anak mendapat pembelajaran akhlak, mengenali nilai-nilai, asupan moral serta cara-cara pengendalian diri dan mempelajari tingkah laku yang merupakan tampilan keluarganya. Jadi keluarga itu bagi individu betul-betul merupakan simbol nilainilai mulia yang dapat menanamkan keimana yang teguh, kesetiaan dan pengorbanan untuk kebersamaan, cinta dan kasih sayang yang akan diaplikasikan bagi kehidupannya kelak bila anak dewasa.

Akhlak merupakan pondasi (dasar) yang utama dalam pembentukan pribadi manusia yang seutuhnya. Menurut Ramayulis, Pendidikan yang mengarah pada terbentuknya pribadi berakhlak, merupakan hal pertama yang harus dilakukan sebab akan melandasi kestabilan kepribadian manusia secara keseluruhan. Pembinaan akhlak di rumah tangga meliputi aspek-aspek, yaitu:

\section{Akhlak dengan Allah SWT}

Akhlak dengan Allah SWT dapat ditingkatkan dengan melakukan ibadah. Dalam beribadah manusia dilatih rohaninya agar rohani tersebut menjadi suci. Apabila rohani seseorang sudah suci maka ia akan dapat mendekatkan diri kepada tuhan. Dengan mengerjakan sholat, puasa, zakat, haji; rohani manusia bisa menjadi bersih dan tidak akan lupa dengan tuhan.

2. Akhlak dengan manusia dan sekitarnya

Akhlak bagi manusia ternyata dapat juga ditingkatkan dengan ibadah. Ibadah dalam ajaran Islam merupakan mata uang yang mempunyai dua sisi. Sisi pertama sebagai pembinaan akhlak kepada Allah SWT dan sisi kedua sebagai pembinaan akhlak kepada manusia. 
Ibadah dalam al-Qur'an berkaitan dengan taqwa yang berarti melaksanakan perintah tuhan dan menjauhkan laranganNya. Perintah tersebut adalah perbuatan baik sedangkan laranga perbuatan yang harus ditinggalkan.

Disamping itu, al-Qur'an dan hadits membawa ajaran-ajaran atau norma moral yang harus dipegang dan diamalkan oleh setiap umat Islam. Sebagaimana Firman Allah SWT dalam surat an-Nahl: 90 sebagai berikut:

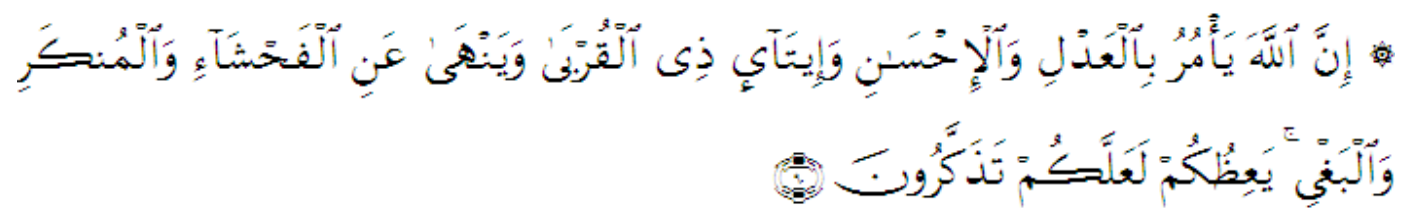

Sesungguhnya Allah menyuruh (kamu) berlaku adil dan berbuat kebajikan, memberi kepada kaum kerabat, dan Allah melarang dari perbuatan keji, kemungkaran dan permusuhan. Dia memberi pengajaran kepadamu agar kamu dapat mengambil pelajaran.

Begitu juga dalam surat al-Hujurat: 12 yaitu:

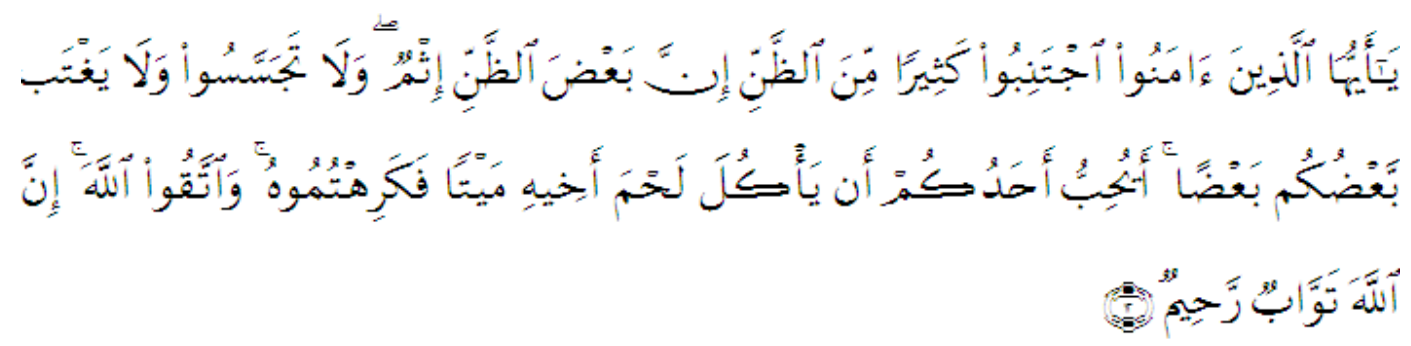

Hai orang-orang yang beriman, jauhilah kebanyakan dari prasangka, sesungguhnya sebagian prasangka itu adalah dosa dan janganlah kamu mencari-cari kesalahan orang lain dan janganlah sebahagian kamu menggunjing sebahagian yang lain. Sukakah salah seorang di antara kamu memakan daging saudaranya yang sudah mati? Maka tentulah kamu merasa jijik kepadanya. Dan bertakwalah kepada Allah. Sesungguhnya Allah Maha Penerima taubat lagi Maha Penyayang. 
Memang berat untuk membangun pribadi manusia dengan akhlak yang baik karena kan berhadapan dengna berbagai macam kendala dan pengorbanan, baik dari luar dan dari dalam dirinya sendiri. Menguasai hanwa nafsu serta mengendalikan diri dari sifat-sifat egois merupakan suatu pekerjaan yang tidak mudah.

Maka dari itu keluarga harus berusaha menanamkan pendidikan akhlak sedini mungkin dengan cara:

1. Memberikan contoh teladan yang baik terhadap anak-anaknya

2. Mengajarkan anak berakhlak baik dan melarang berbuat jahat dengan cara lemah lembut dan penuh kasih sayang sehingga anak menjadi simpati.

Keterikatan seseorang (individu) dengan keluarga tidaklah hanya waktu kecil saja, tetapi ia membutuhkan keluarga sepanjang hidupnya sebab didalam keluargalah baik anak-anak, remaja, orang dewasa dan orang tua mendapatkan kasih sayang, rasa aman dan ketenteraman.

Keberadaan keluarga tidak hanya penting bagi seorang individu tetapi penting pula bagi masyarakat karena masyarakat menempatkan keluarga sebagai institusi sosial yang penting dan merupakan unit sosial yang utama untuk mempersiapkan individu-individu yang akan menjadi anggota dalam masyarakat. Keluargalah yang mengisi individu-individu dengan nilai-nilai budaya, ketaqwaan, moral dan hukum, sosial dan budaya. Dilihat dari peranan dari keluarga yang luas tersebut makanya keluarga dijadikan tolak ukur dalam masyarakat. Misalnya, bila masing-masing keluarga itu baik atau sehat maka akan sehatlah masyarakatntya dan begitu juga sebaliknya.

Ikatan kemasyarakatan yang kuat mendorong orang untuk berbuat tolong menolong sesama, bila ditimpa musibah atau kemalangan. Perbuatan demikian merupkaan pencerminana keimanan seseorang seperti tercermin dalam ungkapan Nabi melalui sabdanya:

"Demi Allah tidak beriman, demi Allah Allah tidak beriman. Maka
ditanyakan oleh sahabat: "Siapakah ia, Ya Rasul?”, beliau 
menjawab: “orang yang tidur kekenyangan sedangkan tetangganya kelaparan, padahal ia mengetahuinya”.

Dari hadits diatas dapat diketahui bahwa seseorang yang tidak memiliki kepekaan sosial dalam bermasyarakat tidak dapat dikatakan sebagai orang yang beriman.

Sikap ta'aruf atau solidaritas hendaknya harus menjadi teladan di zama yang serba egois ini. Kenapa tidak, perbedaan anatara yang kaya dengan yang miskin makin menjolok di dalam masyarakat. Rasa mementingkan diri sendiri sangat menonjol sedangkan kepedulian terhadap penderitaan orang lain semakin menipis. Kebencian dan kecemburuan sosial sering kali timbul disertai rasa dengki terhadap orang lain. Hal tersebut akan merusak kehidupan sosial di tingahtengah masyarakat.

\section{Peranan Keluarga dalam Mengisi Pendidikan Nilai}

Keluarga adalah merupakan pilar utama tempat anak-anak dibesarkan, maka perannya sangat penting untuk memberikan pengisian pendidikan nilai bagi anak-anak. Unsur pertama yang akan ditemui dan dilihat anak serta dirasakan sebelum yang lain adalah keluarga. Maka peranan keluarga dalam pengisian pendidikan nilai bagi anak-anak tidak akan pernah tergusur oleh institusi-institusi lain dan lembaga-lembaga pendidikan yang ada, mulai dari TK, SD, SMP dan seterusnya. Begitu pula halnya dengan lembaga-lembaga sosial budaya, kesehatan, politik lainya tidak akan pernah menggeser peran keluarga dalam mengisi pendidikan nilai secara keseluruhan.

Bagaimanapun tingginya tingkat perkembangan dan perubahan yang terjadi pada sebaghagian masyarakat modern termasuk masyarakat muslim sendiri. Namun peran keluarga dalam mengisi pendidikan nilai tidak akan pernah tergantikan. Karena itu adalah merupakan tugas abadi keluarga yang tidak bisa dipungkiri seperti menyiapkan sifat cinta mencintai antara sesama anggota pertama berakar di dalam kehidupan keluarga. Begitu juga keluarga secara realita berperan sangat besar dalam menanamkan perhatian terhadap pemeliharaan kesehatan, spiritual akhlak, perkembangan intelektual jasmani dan rohani. 
Psikologi modern pun menekankan bahwa keluarga memiliki fungsi yang penting dalam pendidikan dalam pembicaraan jiwa, menanamkan rasa cinta, kasih sayang dan keetnteraman. Sebaliknya justru para ahli ilmu jiwa muslim jauh sebelumnya juga menekankan perkara serupa dalam tulisannya. Ulama muslim dengan tegas menyatakan babhwa keluarga punya potensi besar khusus dalam penularan pendidikan nilai bagi anak-anak. Disamping itu, al Qur'an dan Sunnah banyak menekankan pentingnya pendidikan nilai dijalankan dalam keluarga. Sebagaimana firman Allah SWT dalam surat at-Tahrim: 6, sebagai berikut:

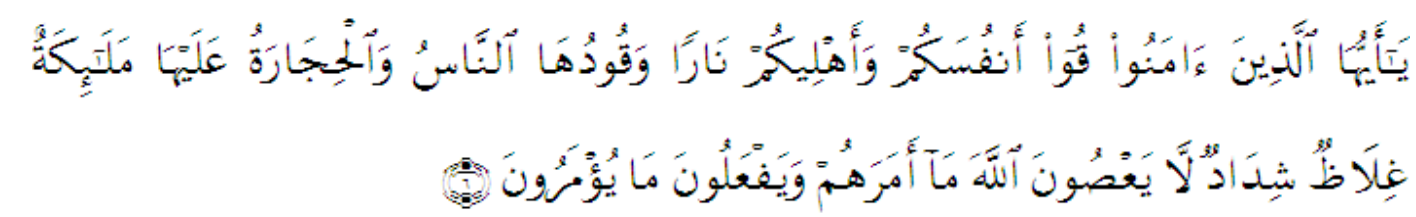

"Hai orang-orang yang beriman, peliharalah dirimu dan keluargamu dari api neraka yang bahan bakarnya adalah manusia dan batu; penjaganya malaikat-malaikat yang kasar, yang keras, yang tidak mendurhakai Allah terhadap apa yang diperintahkanNya kepada mereka dan selalu mengerjakan apa yang diperintahkan"

Rasulullah SAW juga bersabda:

“Awasilah anak-anakmu dan perbaikilah adabnya” (HR. Ibn Majah)

Dari fakta-fakta yang ada diatas menunjukkan bahwa peran mendidik anak adalah kewajiban utama; tidak dapat di tinggalkan kecuali karena uzur, apalagi pendidikan nilai bagi anak-anak, maknanya begitu berarti untuk menentukan kepribadiannya. Nilai-nilai aqidah, ibadah dan nilai-nilai akhlak sangat perlu dimiliki anak-anak. Karena dengan Aqidah (keyakinan) yang kuat terhadap Allah SWT, maka anak akan mempunyai mental yang kuat untuk berhadapan dengan bermacam-macam godaan yang akan merusak keimanannya. Begitu pula dengan pendidikan akhlak sangat berarti menetukan baik/ buruk akhlak seorang anak. Namun pendidikan sosialpun punya makna tersendiri karena manusia adalah 
makhluk sosial yang tidak akan bisa eksis tanpa berada di tengah-tengah manusia lainnya. Untuk itu setiap individu yang menginginkan keberadaannya diakui oleh manusia lain dituntut untuk memilki kepekaan sosial yang tinggi untuk dapat bersosialisasi dengan manusia lainnya.

\section{Metode Penanaman Pendidikan Nilai Oleh Keluarga Kepada Anak}

Keluarga mempunyai peranan yang sangat penting dalam pendidikan psikologikal dan emosional. Melalui pendidikan keluarga dapat membantu anakanak menciptakan perubahan emosi yang sehat, kematanga emosi yang sesuai dengan umurnya, menciptakan penyesuaian psikologikal yang sehat dengan dirinya dan orang-orang disekitarnya serta menumbuhkan emosi kemausiaan yang terpuji seperti menyayangi dan mengasihi fakir miskin, orang yang teraniaya, kehidupan emosi yang rukun dengan orang lain dan mampu menghadapi masalahmasalah psikologikal secara positif dan dinamis.

Hal diatas sesuai dengan sabda Rasulullah SAW yang diriwayatkan dari Aisyah R.A:

“Telah datang seorang Badwi kepada Rasulullah SAW, lalu beliau bertanya: "adakah kamu suka mencium anak-anakmu". Sang badwipun menjawab: "Aku tidak pernah mencium mereka". Rasulullah bersabda: "Sungguh Allah telah mencabut dari hatimu rasa kasih sayang" (HR. Bukhari dan Muslim).

Selain pendidikan psikologikal dan emosional, pendidikan nilai yang seharusnya mendapat prioritas utama diberikan kepada anak-anak adalah pendidikan spiritual. Hal itu dianjurkan agar anak-anak dapat membangkitkan kekuatan agama yang bersifat naluri yang ada pada anak melalui bimbingan agama yang baik untuk diamalkan dalam kehidupannya.

Untuk mencapai hasil yang diharapkan maka ada metode yang dapat digunakan keluarga sebagai berikut:

1. Memberi tauladan yang baik tentang iman dan ajaran-ajaran agama secara kontiniu. 
2. Membiasakan anak melaksanakan ajaran agama dari kecil, hingga hal itu menyatu dengan dirinya serta senang dalam mengerjakannya.

3. Mengajak anak terlibat dalam kegiatan pembinan spiritual dimana saja.

Untuk melakukan penanaman nilai akhlak terhadap anak ada beberapa cara diantaranya:

1. Hendaklah diberikan contoh berakhlak yang mulia kepada anak.

2. Memberi peluang dan suasana yang baik unuk anak dalam mempraktekkan akhlak yang baik.

3. Memberi tanggungjawab pada anak agar bisa bertindak sesuai pilihannya.

4. Menjaga agar anak jauh dari teman-teman yang rusak akhlaknya.

Metode untuk menanamkan nilai-nilai sosial pada anak seharusnya tidak terlepas dari membimbing tingkah laku sosial, ekonomi dan politik dan mendorong anak untuk dapat mengaplikasikan kemampuannya, berproduksi, meghargai waktu, bersikap jujur, ikhlas dalm melakukan sesuatu, adil, kasih sayang, ihsan, peduli dengan sesama, tolong-menolong, setia kawan, cinta tanah air bangsa dan negara. Tindakan yang dapat dilakukan untuk mendidik nilai sosial diantaranya adalah:

1. Memberi contoh perilaku sosial yang cocok dengan prinsip-prinsip sosial dan agama.

2. Membuat suasana dalam keluarga untuk dapat melakukan hubungan sosial yang baik.

3. Membimbing anak untuk bertanggungjawab dalam pekerjaan keluarga

4. Membiasakan anak cara-cara makan, minum, tidur, masuk rumah sesuai dengan ajaran Islam

5. Menghindari sifat kasar, seperti menghina, menuduh orang lain di dekat anak

6. Memberi peluang bagi anak berteman dengan orang-orang yang baik

7. Membiasakan anak menentukan pilihannya dalam belajar.

8. Memberi contoh bagaimana bersifat adil sesama anggota keluarga.

9. Membiasakan hidup dengan sederhana.

10. Memotivasi agar mampu hidup berdikari. 


\section{E. Kesimpulan}

Dari pembahasan diatas dapat disimpulkan sebagai berikut:

1. Keluarga mempunyai peranan penting dan bertanggungjawab dalam mengisi dan memberikan pendidikan nilai bagi anak-anak, baik secara langsung atau pun tidak langsung.

2. Pendidikan nilai bagi anak-anak sebaiknya ditanamkan mulai dari semenjak kecil dan akan lebih baik lagi saat anak berada dalam rahim ibunya.

3. Metode penanaman pendidikan nilai hendaklah bernuansakan aqidah.

4. Untuk mengisi nilai-nilai sosial dapat diberikan sesuai dengan situasi dan mengacu pada tujuan yang diinginkan agar dilaksanakan oleh anak. Artinya metode yang diberikan dapat bersifat fleksibel.

\section{DAFTAR BACAAN}

Andalusi, Imam Ibn Abi Jamrah. (1979). Bahsât an-Nufūs wa Tahallihâ Bima'rifati mâ Lahâ wa mâ Alaihi (Syârah Mukhtasar Shahih al- Bukhâri) Jam'u an Nihâyah fi bad'i al-Khairi wa an-Nihâyah. Beirut: Dârul Jii,.

Anwar, Qomari. (2003) Pendidikan Sebagai Karakter Budaya Bangsa. Jakarta: UHAMKA Press.

Alfurqan, Rahman R, and Rezi M. (2017) Pendidikan Orang Dewasa Yang Dikembangkan Rasullullah. Islam Transformatif : Journal of Islamic Studies 1, No. 1 Hal 15-29. https://doi.org/10.30983/it.v1i1.327.

Alfurqan, Harmonedi. (2017). Pandangan Islam Terhadap Manusia: Terminologi Manusia dan Konsep Fitrah serta Implikasinya dengan Pendidikan. Journal Educative: Journal of Educational Studies 2, No. 2 Hal 129-144.

Arsyad, S.A. 2010. Character Education, Disajikan Pada Sarsehan Nasional Pendidikan Karakter. Dikti Kementerian Pendidikan Nasional di Hotel Murcure Pontianak, Tanggal 17 April 2010.

Abu Ahmadi, dkk. 1991. Ilmu Sosial Dasar. Rineka Cipta: Jakarta 
Eli M.Setiadi. 2006. Ilmu Sosial dan Budaya Dasar. Kencana: Jakarta

Hasan Langgulung. 1989. Manusia dan Pendidikan: Suatu Analisa Psikologi dan Pendidikan. Pustaka Al Husna: Jakarta

M. Arifin. 1991. Ilmu Pendidikan Islam: Suatu Tinjauan Teoritis dan Praktis Berdasarkan Pendekatan Interdisipliner. Bumi Aksara: Jakarta

Ramayulis. 2001. Pendidikan Islam dalam Rumah Tangga. Kalam Mulia: Jakarta 